\title{
Unit Cost Analysis of Laboratory Services in Naili DBS Hospital in 2007 Using Activity Based Costing (ABC) Method
}

\author{
Ressa Oashttamadea ${ }^{1}$, Menkher Manjas $^{2}$, Yurniwati $^{3}$ \\ \{oashttamadea@yahoo.com ${ }^{1}$ \} \\ Faculty of Medicine, Universitas Andalas, Padang, Indonesia ${ }^{1}$ \\ Department of Orthopaedic Surgery, M Djamil Hospital, Teaching Hospital of Universitas Andalas, \\ Padang, Indonesia ${ }^{2}$ \\ Department of Accounting, Faculty of Economics, Universitas Andalas, Padang, Indonesia ${ }^{3}$
}

\begin{abstract}
Activity-based costing (ABC) is an accounting method that identifies and assigns costs to overhead activities. It provides more accurate information about cost so that the hospital can boost its financial efficiency and efficacy as stated in their strategic planning. Laboratoryisoneofthebusiestunitswhich has a big role for doctors in diagnostic procedures. This study aimed to elaborate the regulation and to examine the unit cost of laboratory services atNaili DBS Hospital in 2017 using the ABC method. This research was a mixed method study carried out in 2018. First, it was conducted by interviewing five informants regarding the hospital's unit cost regulation and then by calculating laboratory services' unit costs based on the ABC method. The qualitative study showed that Naili DBS Hospital determines their unit cost using traditional accounting system which has no control over their resource usage. On the other hand, the quantitative study showed that unit cost of routine blood count and clotting \& bleeding time examinations were overcosted (by Rp45.389 and Rp33.904, respectively) and random blood sugar is undercosted (by Rp33.904). This study suggests that Naili DBS Hospital should evaluate their laboratory services' unit cost, review the use of their resources, and hold training about the ABC method.
\end{abstract}

Keywords: Activity-Based Costing, Laboratory Services, Unit Cost.

\section{Introduction}

Hospitals should be able to provide health services for the society with the best quality and reasonable price. Thus, they need an actual cost of the services they provide. A cost accounting method is used to determine the unit cost of hospital services. The information helps hospitals to plan their budget and prices, to identify inefficient budget allocation, and to predict the impact it might cause to their resources [1],[2].

Currently, there is two most commonly used cost accounting method. Those are traditional and activity-based costing (ABC). The traditional method only assigns production cost to the product, but not the overhead. Meanwhile, ABC method allocates activity price to cost objects [2],[3].

Hospital is an institution for individual holistic healthcare, and one of the most widely used services in it is clinical laboratory unit which provides a variety of tests. Unit cost analysis is 
important to determine the actual cost of laboratory services so that it can be used to make decisions and project future financial planning. ABC method, in this case, can analyse more accurately the relationship between cost and activities compared to traditional method [4].

Naili DBS Hospital is one of many private hospitals in Padang. Its laboratory unit provides a wide range of tests such as haematology, hemostatics, kidney and liver function, blood sugar, lipid, and urine. During January to October 2017, it has already performed 12,133 tests, with an average of 1,213 tests per month. Most of the tests performed were routine blood count, random blood sugar, and clotting and bleeding times. In determining the fares, this hospital calculated used resources, set doctor salaries and then compared it against other private hospitals in Padang. This condition could result in that customers do not pay for the actual cost of the services. The fares could be undercounted or overcosted compared to the resources they have consumed. This could make the laboratory unprofitable shortly. To address the issue, this study was conducted to determine the unit cost of laboratory services in order to provide the basis for setting real fares.

\section{Materials and Methods}

This mixed method study was conducted in 2018 at a clinical laboratory unit of Naili DBS Hospital. A qualitative study was conducted by interviewing five informants for information regarding laboratory fares regulation. They were hospital director, vice director of medical services, vice director of general and finance, head of accounting, and head of the laboratory unit. Topics of the interview include the concept to determine laboratory service unit costs, regulation to control the use of resources, and problems regarding unit cost.

On the other hand, quantitative study was conducted by observation and documentation in other departments that relate to unit costs of laboratory services, such as accounting, logistics, medical services committee, pharmacy, and clinical laboratory itself. After documenting, all data were analyzed based on the ABC method.

Unit cost was calculated through the following five steps. The first step was identifying and assigning a cost to activities, followed by classifying activities according to cost centres and by identifying cost drivers. The fourth step was costing itself, followed by attributing costs to products.

\section{Results}

Qualitative study showed that Naili DBS Hospital did not set a regulation to determine each department's unit cost. Current fares were calculated by analysing the resources consumed and salaries paid by the hospital, which then benchmarked to nearby private hospitals. Moreover, this hospital did not include incentives, administration and stationery costs to its unit cost.

Naili DBS Hospital did make a regulation on how to procure logistics but not about controlling supplies. Head of the department's assigned procurement to logistics, which are provided afterwards by the logistics. However, there were no rules on how to control the consumption of the resources.

Problems regarding laboratory services that the hospital faced were that they did not know about the profit and loss of the unit. Therefore in the future, the management hoped to be able to fix their unit cost so it could express their actual profitability. 
The quantitative study was calculated based on the ABC method with the following steps:

Calculation of per unit cost was shown in Table 1 . The costs per unit for each activity were Rp8,046 for lab analyst salary, Rp6,561 for doctor salary, Rp269,374 for operational cost, Rp2,000 for administration cost, Rp291,943 for cleaning and security, Rp7,470 for consumable medical resources, Rp334 for stationery, Rp236,516 for building depreciation, and Rp492 for facility depreciation.

Based on cost per unit, the unit cost calculated for each laboratory tests are shown in Table 2, Table 3, and Table 4.

Table 1. Calculating Cost Per Unit based on the ABC Method.

\begin{tabular}{|c|c|c|c|c|}
\hline $\begin{array}{l}\text { Activity } \\
\text { Unit level activity cost }\end{array}$ & Driver & total & \multicolumn{2}{|c|}{ Cost driver cost per unit } \\
\hline $\begin{array}{l}\text { Unit level activity cost } \\
\text { a. Lab analyst salary } \\
\text { 1. Routine blood count } \\
\text { 2. Random blood sugar } \\
\text { 3. Clotting and bleeding times }\end{array}$ & $\begin{array}{l}\text { number of tests } \\
\text { number of tests } \\
\text { number of tests } \\
\text { number of tests }\end{array}$ & Rp89,948,116 & $\begin{array}{l}11,179 \\
2,587 \\
2,238 \\
1,077\end{array}$ & Rp8,046 \\
\hline $\begin{array}{l}\text { b. Doctor salary } \\
\text { 1. Routine blood count } \\
\text { 2. Random blood sugar } \\
\text { 3. Clotting and bleeding times }\end{array}$ & $\begin{array}{l}\text { number of tests } \\
\text { number of tests } \\
\text { number of tests } \\
\text { number of tests }\end{array}$ & $\mathrm{Rp} 73,342,851$ & $\begin{array}{l}11,179 \\
2,587 \\
2,238 \\
1,077\end{array}$ & Rp6,561 \\
\hline $\begin{array}{l}\text { c. Operational cost } \\
\text { 1. Routine blood count } \\
\text { 2. Random blood sugar } \\
\text { 3. Clotting and bleeding times }\end{array}$ & $\begin{array}{l}\text { floor area }\left(\mathrm{m}^{2}\right) \\
\text { floor area }\left(\mathrm{m}^{2}\right) \\
\text { floor area }\left(\mathrm{m}^{2}\right) \\
\text { floor area }\left(\mathrm{m}^{2}\right) \\
\end{array}$ & $\mathrm{Rp} 410,526,317$ & $\begin{array}{l}1,524 \\
3,8 \\
3.3 \\
1.6\end{array}$ & Rp269,374 \\
\hline \multicolumn{5}{|l|}{ Batch related activity cost } \\
\hline $\begin{array}{l}\text { a. Administration cost } \\
\text { 1. Routine blood count } \\
\text { 2. Random blood sugar } \\
\text { 3. Clotting and bleeding times }\end{array}$ & $\begin{array}{l}\text { number of tests } \\
\text { number of tests } \\
\text { number of tests } \\
\text { number of tests }\end{array}$ & $\mathrm{Rp} 22,358,000$ & $\begin{array}{l}11,179 \\
2,587 \\
2,238 \\
1,077\end{array}$ & $\mathrm{Rp} 2,000$ \\
\hline $\begin{array}{l}\text { b. Cleaning and security } \\
\text { 1. Routine blood count } \\
\text { 2. Random blood sugar } \\
\text { 3. Clotting and bleeding times }\end{array}$ & $\begin{array}{l}\text { floor area }\left(\mathrm{m}^{2}\right) \\
\text { floor area }\left(\mathrm{m}^{2}\right) \\
\text { floor area }\left(\mathrm{m}^{2}\right) \\
\text { floor area }\left(\mathrm{m}^{2}\right)\end{array}$ & $\mathrm{Rp} 444,921,724$ & $\begin{array}{l}1,524 \\
3.8 \\
3.3 \\
1.6\end{array}$ & Rp91,943 \\
\hline $\begin{array}{l}\text { c. Consumable medical resources } \\
\text { 1. Routine blood count } \\
\text { 2. Random blood sugar } \\
\text { 3. Clotting and bleeding times }\end{array}$ & $\begin{array}{l}\text { number of tests } \\
\text { number of tests } \\
\text { number of tests } \\
\text { number of tests }\end{array}$ & Rp83,504,512 & $\begin{array}{l}11,179 \\
2,587 \\
2,238 \\
1,077\end{array}$ & $\mathrm{Rp} 7,470$ \\
\hline $\begin{array}{l}\text { d. Stationery } \\
\text { 1. Routine blood count } \\
\text { 2. Random blood sugar } \\
\text { 3. Clotting and bleeding times }\end{array}$ & $\begin{array}{l}\text { number of tests } \\
\text { number of tests } \\
\text { number of tests } \\
\text { number of tests }\end{array}$ & Rp3,730,500 & $\begin{array}{l}11,179 \\
2,587 \\
2238 \\
1077\end{array}$ & Rp334 \\
\hline $\begin{array}{l}\text { Facility sustaining activity } \boldsymbol{c} \\
\text { a. Building depreciation } \\
\text { 1. Routine blood count }\end{array}$ & $\begin{array}{l}\text { floor area }\left(\mathrm{m}^{2}\right) \\
\text { floor area }\left(\mathrm{m}^{2}\right)\end{array}$ & $\mathrm{R} 360,450,000$ & $\begin{array}{l}1,524 \\
3.8\end{array}$ & Rp236,516 \\
\hline
\end{tabular}




\begin{tabular}{|c|c|c|c|c|}
\hline 2. Random blood sugar & floor area $\left(\mathrm{m}^{2}\right)$ & & 3.3 & \\
\hline 3. Clotting and bleeding times & floor area $\left(\mathrm{m}^{2}\right)$ & & 1.6 & \\
\hline Facility depreciation & number of tests & Rp5,500,000 & 11,179 & Rp492 \\
\hline 1. Routine blood count & number of tests & & 2,587 & \\
\hline 2. Random blood sugar & number of tests & & 2,238 & \\
\hline 3. Clotting and bleeding times & number of tests & & 1,077 & \\
\hline
\end{tabular}

Table 2. Assigning Cost to Product: Routine Blood Count Test.

\begin{tabular}{|c|c|c|c|c|}
\hline No & Activity & Cost Per Unit & Driver & total $(\mathrm{Rp})$ \\
\hline 1 & Lab analyst salary & Rp8,046 & 2,587 & Rp20,815,438 \\
\hline 2 & Doctor salary & Rp6,561 & 2,587 & Rp16,972,713 \\
\hline 3 & Operational cost & Rp269,374 & 88.7 & Rp23,893,494 \\
\hline 4 & Administration cost & Rp2,000 & 2,587 & Rp5,174,000 \\
\hline 5 & Cleaning and security & Rp291,943 & 3.8 & Rp1,109,385 \\
\hline 6 & Consumable medical resources & $\mathrm{Rp} 7,470$ & 2587 & Rp19,324,284 \\
\hline 7 & Stationery & $\mathrm{Rp} 334$ & 2,587 & Rp863,298 \\
\hline 8 & Building depreciation & Rp236,516 & 3.8 & Rp898,760 \\
\hline 9 & Facility depreciation & $\mathrm{Rp} 492$ & 2,587 & $\mathrm{Rp} 1,272,788$ \\
\hline \multicolumn{4}{|c|}{ Total cost for routine blood count } & Rp90,324,159 \\
\hline \multicolumn{4}{|c|}{ Number of patients } & 2,587 \\
\hline \multicolumn{4}{|c|}{ Unit cost per patient } & Rp34,915 \\
\hline \multicolumn{4}{|c|}{ Profit $(30 \%)$} & Rp10,474 \\
\hline \multicolumn{4}{|c|}{ Fare } & Rp45,389 \\
\hline
\end{tabular}

Table 3. Assigning Cost to Product: Random Blood Sugar Test.

\begin{tabular}{|c|c|c|c|c|}
\hline No & Activity & Cost Per Unit & Driver & total $(\mathrm{Rp})$ \\
\hline 1 & Lab analyst salary & Rp8,046 & 2,238 & Rp18,007,325 \\
\hline 2 & Doctor salary & Rp6,561 & 2,238 & Rp14,683,004 \\
\hline 3 & Operational cost & Rp269,374 & 3.3 & Rp889,810 \\
\hline 4 & Administration cost & $\mathrm{Rp} 2,000$ & 2,238 & Rp4,476,000 \\
\hline 5 & Cleaning and security & Rp291,943 & 3.3 & Rp964,361 \\
\hline 6 & Consumable medical resources & $\mathrm{Rp} 7,470$ & 2,238 & Rp16,717,336 \\
\hline 7 & Stationery & Rp334 & 2,238 & Rp746,834 \\
\hline 8 & Building depreciation & Rp236,516 & 3.3 & Rp781,270 \\
\hline 9 & Facility depreciation & Rp492 & 2,238 & $\mathrm{Rp} 1,101,082$ \\
\hline \multicolumn{4}{|c|}{ Total cost for random blood sugar } & Rp58,367,022 \\
\hline \multicolumn{4}{|c|}{ Number of patients } & 2,238 \\
\hline \multicolumn{4}{|c|}{ Unit cost per patient } & Rp26,080 \\
\hline \multicolumn{4}{|c|}{ Profit $(30 \%)$} & $\operatorname{Rp} 7,824$ \\
\hline \multicolumn{4}{|c|}{ Fare } & Rp33,904 \\
\hline
\end{tabular}

Table 4. Assigning Cost to Product: Clotting Time \& Bleeding Time Test.

\begin{tabular}{lllll}
\hline No & Activity & Cost Per Unit & Driver & Total (Rp) \\
\hline 1 & Lab analyst salary & Rp8,046 & 1,077 & Rp8,665,723 \\
2 & Doctor salary & Rp6,561 & 1,077 & Rp7,065,950 \\
3 & Operational cost & Rp269,374 & 1.6 & Rp428,206 \\
4 & Administration cost & Rp2,000 & 1,077 & Rp2,154,000
\end{tabular}




\begin{tabular}{lllll}
5 & Cleaning and security & $\mathrm{Rp} 291,943$ & 1.6 & $\mathrm{Rp} 464,083$ \\
6 & Consumable medical resources & $\mathrm{Rp} 7,470$ & 1,077 & $\mathrm{Rp} 8.044,938$ \\
7 & Stationery & $\mathrm{Rp334}$ & 1,077 & $\mathrm{Rp359,401}$ \\
8 & Building depreciation & $\mathrm{Rp} 236,516$ & 1.6 & $\mathrm{Rp375,973}$ \\
9 & Facility depreciation & $\mathrm{Rp} 492$ & 1,077 & $\mathrm{Rp529,877}$ \\
\hline Total cost for CT \& BT & & & $\mathrm{Rp28,088,151}$ \\
Number of patients & & 1,077 \\
Unit cost per patient & & $\mathrm{Rp26,080}$ \\
Profit $(30 \%)$ & & $\mathrm{Rp7,824}$ \\
Fare & & $\mathrm{Rp33,904}$ \\
\hline
\end{tabular}

After calculation performed based on the ABC method, profit was added to set the fares. The fares for routine blood count was Rp 45,389, random blood sugar was Rp 33,904, and clotting and bleeding times was Rp 33,904. They are then compared to previous unit cost based on the traditional method.

Table 5. Fares Comparison between Traditional and ABC Method.

\begin{tabular}{llccl}
\hline No & Pemeriksaan & $\begin{array}{l}\text { Traditional } \\
\text { method }\end{array}$ & Abc method & Gap \\
\hline 1 & Routine blood count & Rp84,000 & $\mathrm{Rp} 45,389$ & $\mathrm{Rp} 38,611$ \\
2 & Random blood sugar & $\mathrm{Rp} 21000$ & $\mathrm{Rp33,904}$ & $\mathrm{Rp}(12,904)$ \\
3 & Clotting time \& bleeding time & $\mathrm{Rp} 42,000$ & $\mathrm{Rp} 33,904$ & $\mathrm{Rp} 8,096$ \\
\hline
\end{tabular}

Based on the calculation, the unit cost of routine blood count and clotting and bleeding times were overcosted by Rp 38.611,- and Rp 8.096,- while random blood sugar was undercosted by Rp 12.904,-.

\section{Discussion}

Activity-based costing is an activity analysis method developed to understand the indirect support costs of decision management or operations. ABC model was initially built up as a single-faceted model. The advantage of the costing system provides the accurate cost information which is based on the production process and activities. A company should be using the cost-plus method in calculating their fares, which is conducted by analysing the unit cost first and then set the profit for the company. However, it should be done carefully because high unit cost means higher fares that could lead to losing market competitiveness [5]. Currently, Naili DBS Hospital has not set any regulation regarding their laboratory services unit cost. To increase their competitiveness in the market, the hospital should review their fares by identifying activities related to cost objects so it would provide more accurate cost.

Naili DBS hospital has had a regulation to procure consumable medical resources and logistics but has not yet had a regulation to control the use of the resources. Regarding this matter, the business process is the accumulation of activities that change the input to output which impacts the unit cost of a product. Every business process needs planning, implementation, controlling, and evaluation to create a product. Every process should be done right by following standards, but in reality, there's always a problem in the field that holds the hospital from reaching the target and risks in financial loss in laboratory unit [6,7]. Therefore, 
this hospital needs to set a regulation to control and evaluate the use of the resources so that they can evaluate their company's business process related to performance, efficiency, and reliability so prevent financial loss.

Cost analysis for routine blood count based on the ABC method was lower compared to current hospital fares. To perform routine blood count, laboratory unit used a haematology analyser that provides parameters related to haematology in one usage. In this regard, unit cost calculations should be performed comprehensively. However, the hospital imparts a Rp21,000 tariff for every parameter examined. This results in a four-parameter routine haematology examination being charged Rp84,000 or four times examination tariff. This is the cause of the current tariff overcoating.

Cost analysis for clotting \& bleeding times based on the ABC method was also lower compared to current hospital rates. It was also the same as a routine blood count test, in which a laboratory analyst only needs to perform once in order to examine cutting and bleeding times. However, this procedure has a tariff of Rp42,000, equal to twice examination tariff. This shows that the hospital has imposed a higher tariff than it should (overpricing).

On the other hand, cost analysis for random blood sugar based on $\mathrm{ABC}$ was higher than hospital current fares. It showed that hospital set lower fare or underpricing. The gap happened because there are differences in allocating overhead costs to products. In traditional accounting method, the overhead cost was allocated based only on unit related cost while it did not include batch, product, and facility sustaining costs. ABC method fixes the accuracy of product pricing, which is important in the decision making process [8].

\section{Conclusions}

Naili DBS Hospital management had not yet set regulation on calculating their unit cost, especially laboratory unit. Current fares were calculated based on the traditional method by managerial meetings. Based on the ABC method, fares for routine blood count is Rp45,389, random blood sugar is Rp33,904, and clotting \& bleeding time is Rp33,904. The fares were overcoating for routine blood count, and clotting \& bleeding time, meanwhile it was undercutting for random blood sugar.

\section{References}

[1] Gujral, S. Activity Based Costing Methodology as Tool for Costing in Hematopathology Laboratory. Indian J Pathol Microbiology 2010: 68-74.

[2] Javid, M., Hadian, M., Ghaderi, H., Ghaffari, S., dan Salehi, Masoud. Application of the ActivityBased Costing Method for Unit Cost Calculation in a Hospital. Global Journal of Health Science 2016; 8: 164-172.

[3] Lestari, W., dan Permana, D. B. Akuntansi Biaya dalam Perspektif Manajerial. Depok: PT RajaGrafindo Persada; 2017.

[4] Mouseli, A., Barouni, M., Amiresmaili, M., Samice, S., dan Vali, L. Cost Price Estimation of Ckinical Laboratory Services Based on Activity Based Costing: A Case Study from A Developing Country. Electronic Physician 2017; 9: 4077-4083.

[5] Lu, T. Y. Competitive Price Strategy with Activity Based Costing. Procedia CIRP 2017; 63: 1420.

[6] Minartiningtyas, B. A. Analisa Proses Bisnis. Diakses di https://kuliah.brigidaarie.com/ wpcontent/uploads/2018/02/Sistem-Informasi-8.pdf pada tanggal 3 Juli 2018 pukul 20:03 WIB. 
[7] Sakti, L. C. Pemodelan dan Evaluasi Proses Bisnis Menggunakan Metode Quality Evaluation Framework $(Q E F)$. Jurnal Pengembangan Teknologi Informasi dan Komputer Vol 1, 2017 : 1500-1507.

[8] Yuliastanti, Nina. Penerapan Sistem Activity Based Costing (Studi Kasus pada Perusahaan Manufaktur Komponen Otomotif). Jakarta: Universitas Indonesia; 2010. 